\title{
VCT (VALUE CLARIFICATION TECHNIQUE) LEARNING MODEL APPLICATION TO IMPROVE HISTORICAL VALUE UNDERSTANDING
}

\author{
Nunuk Suryani ${ }^{1}$
}

\begin{abstract}
Learning the history referred to as the transfer of value. The role of history education is very important in teaching about values, moral and spiritual. By internalizing these values will be formed nationalism in student attitudes. Establishment of nationalistic attitude is important to anticipate the global challenges and a variety of shocks that hit the disintegration of Indonesia recently. Historical experience proves the attitude of nationalism can generate social dynamics in the past. Education history can be said to have educational value if the history of education can contribute to make students become someone who has a wise attitude or have a noble moral values. For history has educative function, then the teacher can make learning history with a moral approach. Moral approach is an approach that emphasizes the value of the meaning contained in the material presented history. Students should be actively involved in learning activities. In order to more meaningful learning history or high value, teachers can use the methods that can internalize the values in it. One is the model of value clarification. Value clarification learning model first used by Louis Raths in the 1950 s while teaching at New York University. VCT learning model (Value Clarification Technique) is a "learning model which to assist students in finding and determining a value that is considered good in dealing with problems through the process of analyzing the existing value in the self-student. This approach will help students understand and find value / meaning of historical events in depth (ultimate meaning). Based on the data analysis it is found that the VCT model to produce an understanding of history better than the conventional models. Students with high emotional quotient have the understanding of historical value better than students with low emotional quotient.
\end{abstract}

Key word: VCT, historical value understanding

\section{Introduction}

IPS (Social Studies) lesson, especially history, often said as the memorize subject and boring. This lesson in merely considered as series of years numbers and events order that has to be remembered and re-explained later to answer the test's questions. That's the reality. It resulted in the low interest of history lesson and this lesson is considered as a light (meaningless) lesson. In fact, the essence of this lesson is not merely that the students have to memorize the facts and the

\footnotetext{
1 Dr. Nunuk Suryani, M.Pd is lecturer in History Education Study Program FKIP UNS. This article has been reviewed by Prof. Dr. Said Hamid Hasan, M.A and Dr. Nana Supriatna, M. Ed (Indonesia University of Education).
} 
year numbers (transfer of knowledge), but to make the students understand about identity by finding out positive values to be learned and left the negative values behind.

History learning process is called as transfer of value and Capra (2004) explained that History lesson is important because it teach about value, moral, and spiritual. History education is very important in teaching about value, moral, and spiritual. By internalisation of those values, nationalism will be developed in the student's identity. The development of nastionalism is important to anticipate the global challenge and various disintegration fluctuation that had happended in Indonesia recently. This is because history proved that nationalism can emerge the social dynamic in the past.

However, today the role of History lesson is in question. The nationalism in this nation is weaker. Conflict between ethnic and religion caused by different values, and the effort of some region to separate themselves from Negara Kesatuan Republik Indonesa, is some prove that the national unity is weak. Moreover, if we see the value developed among the young generation, it has a tendency to be drowned in a new culture that sometimes opposites to this nation culture.

The lack ability in clarifying the history value among students caused by the lack of contextual teaching in history lesson. The learning situation, as said by Lee H. Ehman, that usually happen in the class, especially history, is closed and teacher oriented. Teacher and student relationship pattern is monolog, student participation is limited. The history teaching materisal is textual and is not open enough to the actual problems. This class situation shows lack of democracy atmosphere in history learning process, and thus affect to the students' internalitation of historical values to themselves. Most teachers still teach the history material in a more cognitive way (the student's history facts knowledge). However, history as a learning subject in school has an educative function, beside the cognitif aspect of the knowledge. All this time, in the teaching and learning process, teacher tends to teach the history material that focus in historical events chronologic. In sending the historical message of history lesson, sometimes teacher connect it to the present time contex, that cause the educative value does not have enough attention.

To improve the educative function, in order that history can be used as the life guidance and inspiration of their future, the teachers are forced to be more creative in conveying the teaching materials. By a closed teaching model and focus on the cognitive aspect only, the function of studying history as explained by Kartodirjo and Nugroho Notosusanto will be hard to achieve. According to Kartodirdjo, History teaching has a fundamental function in developing the national identity and history awareness to emerge the sense of nationality and responsibility. According to Nugroho Notosusanto, the functions of studying history are: 1) inspirative function, 2) kosntructive function, and 3) educative function. Inspirative function is to give inspiration about nasionalism attitude that should be inherited by the students and how they should fight to appearing 
that nationalism attitude. Constructive function is by understanding the historical events, by that students are expected to behaved and acted constructively.

History education will have an educative value if the education can develop them to be a wise person or a person with a high morality. In order to give an educative function for history lesson, the history teacher should teach with a moral approach that focused on the values of the history materials conveyed. The students should be acitively involved in the learning activities. The purpose of moral approach in history teaching concept is to make the historical events to be understood by the students as a meaningfull event that can be use as their guidance or role model in the nationhood and statehood. Thus the teaching material as an educative concept/ the education about a nationalism attitude can be developed.

To teach the value of history lesson, of course it cannot be conveyed through the approach of fact teaching (lecture), but we have to use the suitable approaching to make the student understand, comprehend, and internalize historical values to themselve. Therefore, professionally, history teacher should have an undertstanding about the essence of history lesson, the history lesson goals, the competences that can be improved in history lesson, what value needed and can be improved in history lesson, before the teacher find the suitable method or approaching to be applied.

Teacher can use a method that can internalized the values in history lesson, value clarification, to create a more meaningful and qualified history lesson. Value clarification model as a lesson mode was used for the first time by Louis Raths in 1950 s when he taught in New York University. VCT (Value Clarification Technique) lesson mode is "a teaching technique to help the student in finding and determining a good value in facing a problem and value analyzing process that is already available and rooted in the student's identity. This approach will help student to understand and find historical events values/ meaning ultimately.

\section{Explanation of VCT (Value Clarification Technique) lesson mode}

One of the the important factors in determining the successfulness of a learning process is by using the right learning mode. The character and identity implementation through a learning process is not easy, in fact, it is hard and need the in the right learning mode. According to Soenarwan (2008), "model is a reflection of a reality, usually it is a simplification of a reality that is too complex, so it can be observed direcetly" or "a conceptual frame that is used as an activities guidance” (Toeti Soekamto dan Udin Saripuddin Winataputra, 1996).

In addition, Udin Saripuddin Winataputra explain that "learning mode is a conceptual framework with a sitematic procedure in organizing learning experiences to achieve a particular learning goal, and how the teacher plan and conduct the learning-teaching activity" (Toeti Soekamto dan Udin Saripuddin Winataputra, 1996). Therefore, learning mode is a conceptual frame of how a 
learning-teaching process is conducted, both about the learning activities and the teacher.

In implementing the historical values, the learning mode to be developed should be based on the following explanation:

a. Value identification. Value as a lesson target should be identified by the students;

b. Activity. The students are guided to do activities that is directed to the awareness of the targeted values to be learned;

c. Learning aids. Use aids that is suitable with the value topic;

d. Unit interaction. Developing strategies or ways that can aware the students about values;

e. Evaluation segment. Evaluating the value learning progress through various evaluation technique.

According to Peter Martorella as conveyed by Douglas Superka in Hamid Darmadi (2007:), There are eight approach in value education, 1) vocation, 2) inculcation, 3) moral reasoning, 4) value clarification, 5) value analysis, 6) moral awareness, 7) commitment approach, and 8) union approach For the importance of education technical and practice, these eight approaches is summarised into five, 1) inculcation approach, 2) cognitive moral develompment approach, 3) value analysis approach, 4) value clarification approach, dan 5) action learning approach (Zaim Elmurabok, 2008; Nurul Zuriah, 2007).

Value clarification term as a learning process mode was used for the first time by Louis Raths in 1950s when he was teaching in New York University. VCT (Value Clarification Technique) Learning mode is "a teaching technique to help student finding and determining a good value in facing a problem through analysing the value owned already by student" (Wina Sanjaya, 2008; Zaim Elmurabok, 2008:) According to Simon, Sidney B. \& Leland W. Howe (http:// www.ApologeticsPress.org), "value clarification is a complex system of behavioral modification involving various concepts, ideas, and applications”. Accoring to Kirschenbaum in Hamid Darmadi (2007), "value clarification is not value-free or relavistic, but through an affectual shock involving human potential.”

Theoritically, VCT (value clarification technique) learning process is defined in the picture below.

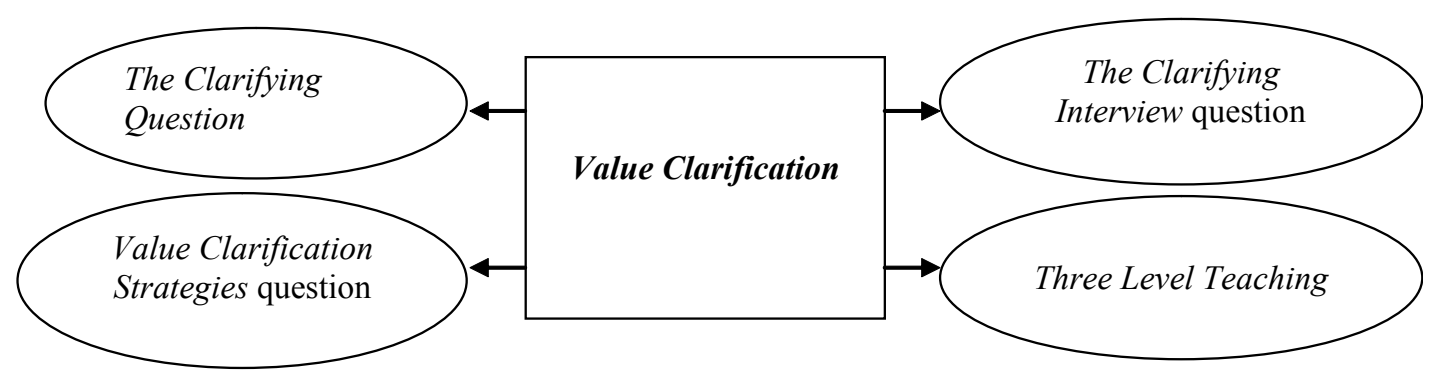

Picture 12.1. Basic Frame of Value Calrification Learning Mode 
The characteristic of $V C T$ learning mode is value impelementation to the students by harmonizing the values that is already owned by the students and new values to be implemented, which Darmiyati Zuchdi (2008) called as "value inquiry process". This harmonization will protect the value stability as the basic of students' character in the value understanding alteration that is more complex because it is found by the student's themselve through a rational process.

\section{The Purpose of VCT (Value Clarification Technique) Learning}

According to Douglas Superka (1976) in Zaim Elmurabok (2008), VCT mode has three goals:

1) Helps students to aware and indentify their own values and others';

2) Helps students to communicate honestly and openly with another based on their own values;

3) Helps students to learn how to use the rational thinking and emotional awareness together, to undertand the feeling, values, and their own behaviour.

Wina Sanjaya (2008) also explains about the goal of value clarification technique learning processes, which are:

1) To measure and undertsnding the students' awareness about values;

2) Develop the awareness of the values they have, both the level and the attitude (the postive and negative), to improve and develop them.

3) To implementing particular values in a rational and acceptable way for the student, and at the end the values will be theirs.

4) Train the student to appreciate, accept, and make a decision of a problem in the conection of the people everyday life.

\section{The Steps of VCT (Value Clarification Technique) Learning}

According to Louis Raths in David Lipe (http://www.ApologeticsPress. org), the value clarification include in three process, 1) choosing, 2) prizing, dan 3) acting. The third level of those steps is as follows, Choosing:

1) freely

2) from alternatives

3) after thouhtful consideration of the consequences of each alterative

Prizing :

4) cherishing, being happy with choice

5) willing to affirm the choice publicly 
Acting :

7) repeatedly, in some pattern of life

According to John Jarolimek in Wina Sanjaya (2008), VCT learning mode has seven steps which are divided into three level.

1) Freedom to choose

There are steps in this level:

a) Freely choose. It means that there is chance to determining a good choice.

b) Chosing from various alternatives, determining from various alternative freely.

c) Chose after analyzing the consequencies as the choice available.

2) Respect

There are two steps in this level:

a) Having a proud and happy feeling on the determined value, so that value will be integrated in his personality.

b) Clarify the value that has been part of his life in front of the public.

3) Act

There a two steps in this level:

c) A desire and ability in tryiing to do it;

d) Repeating an appropriate attitude that will be reflected in everyday life.

According to A. Kosasih Djahiri (1996) in Hamid Darmadi (2007), the application of VCT mode is based on the following design:

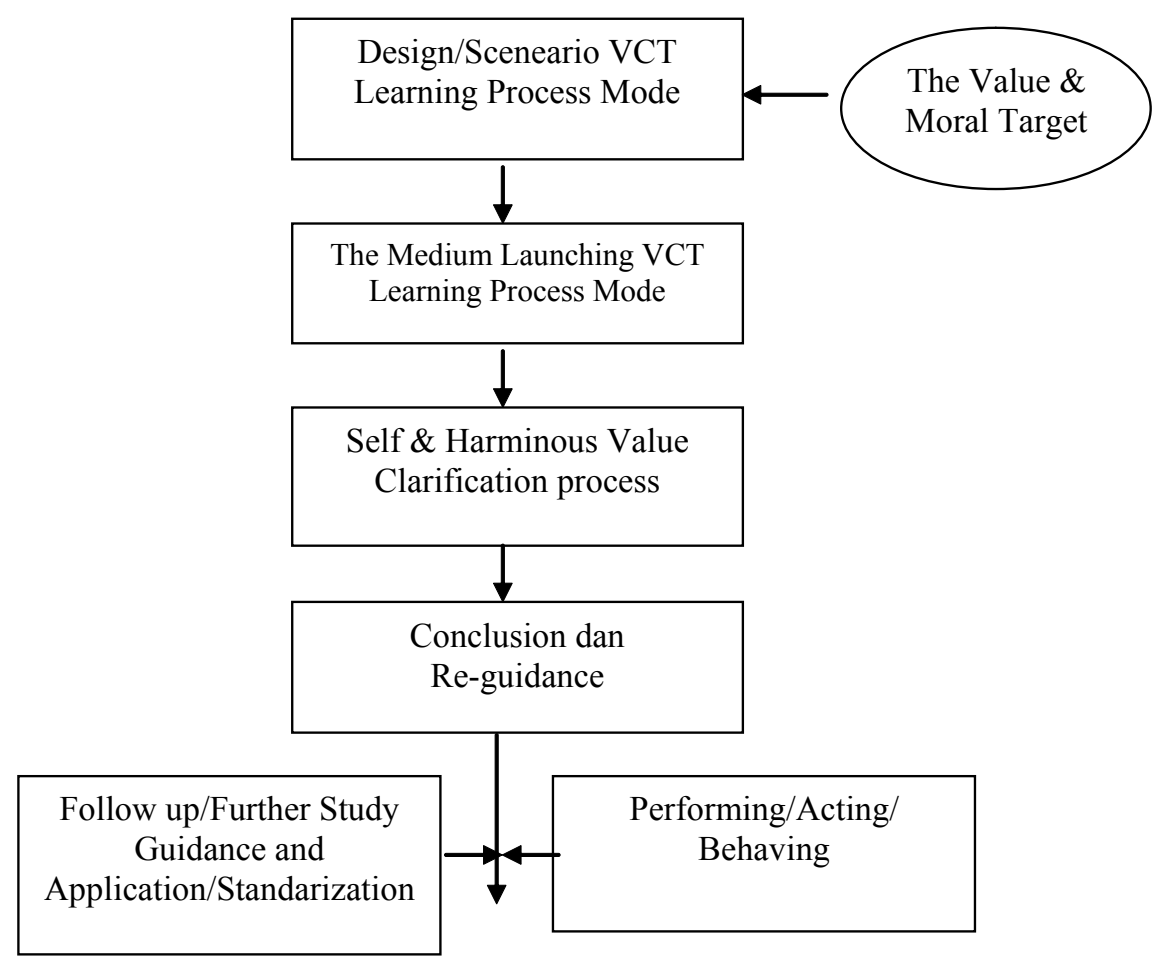

Picture 12.2: The Process and Value Clarification learning model. 
$V C T$ learning mode application is very flexible. Effective learning method are dialogue, writing, small group discussion, large group discussion, observation, pratice, and demonstration.

The teacher role in a learning process is as a role model or a supporter to support the student with various relevance questions to improve the students' skill in measuring and clarificating value. Therefore, below are several things to be considered in VCT mode learning process,

1) Avoid conveying the message through advicing, giving a good moral message.

2) Don't force the students to give a particular respond if the students do not want it.

3) Try to make a free and open dialogue. Therefore, the students will express their feeling honestly.

4) Dialogue is individually, not to group.

5) Avoid any respond that can judge the student and cause the student to be defensive.

6) Do not force student to accept a particular principal.

7) Do not dig up about the students' reason too deep (Wina Sanjaya, 2008).

\section{The Advantages and Disadvantages of VCT (Value Clarification Technique) Learning Mode}

Accoring to A. Kosasih Djahiri in Hermi Zanzi (2008), the advantages of VCT (Value Clarification Technique) are:

1) Develop and personalize value and moral;

2) Clarify and explain the lesson material message;

3) Clarify and measure the quality or students' moral value and the moral value reality;

4) Invite, involve, construct, and improving the student potential, particularly the affectual side;

5) Giving a learning experience in various life;

6) Can avoid, erase, intervent, and subverse various naif moral value that exist in the value and moral system of a student's;

7) Guide and motivate to live properly and morally high.

The VCT (Value Clarification Technique) learning mode gives a direct experience to the students in determining a particular attitude toward any value problems and applying it in everyday life again and again until it is possible to become a habit. It is very important to develop an understanding about historical value, because Zakiah Daradjat in Kunaryo Hadikusumo (2001) said that the early life experience, even in the womb, is the factors for a person personality in the future. 
The weakness of VCT (Value Clarification Technique) learning mode according to Darmiyati Zuchdi (2008) is "it can not help student to cope values conflict because values clarification can implicate in the value relativism and considering that all values the same". In addition, value clarification is a complex behavioural modification because it is associated to concept, idea, and its application. Therefore, in the implementation, it needs a well preparation and a very professional teacher support.

\section{Historical Value Understanding}

Basically, value can be divided into two large groups: values of being and values of giving Values of being is the values in humanself that later grow to an attitude and how we respect another person. The values of being includes: honestly, couragement, peace, skill, potential, discipline, border, purity, and appropriacy. The giving values are the value needed to practice and later will accept as much as what had been given. The group of values includes lotalty, reliable, respect, love, care, sensitivity, selfishness, fair and generous.

Based on philosophical dictionary of Hoffmeister (Zaim Elmurabok, 2008) the definition of value is ".....die Zwischen einen Gegenstand und eine Masztab durch die Werteden Menschen hergestelite Bezicheng”.(the existed realtionship among human who is giving evaluation between a thing in one measurement). Norm means measurement for the valuation and consideration.

Human characteristic - mind, body, feeling, and desire - exists in the human moral value. A collective value in a society is the glue of that society. If a society has a same particular value about what is useful and not uselful, beautiful and not beautiful, the good and the bad, this kind of society seems tied together in the same value. Therefore, this society will have a high solidarity. If this value has become the public property and implemented with a deep emotion, the society member will be willing to sacrifice and fight for the values, such as defending the national flag, which is the national identity and has a particular value.

Improving the understanding of historical value is also affected by internal factor and the environment sorounding the student's life. The student's internal factor is also really complex, physically and mentally. Someone physical condition affects the ability to understand. The mental factor includes motivation, interest, and intelegence. Accoring to Din Zainudin (2004), "the internal factor or genetical factor includes talent, intelegence, and temperament". Intelegence is complex based on the theory development about multiple intelligences, acrotding to Mappadjantji Amien, (2005), "there are three different factors that complete each other, which are intelligence, emotion, and spiritual".

The most improved intelligence today is emotional quotient. Personality is very much associated with emotion. Therefore, the connection between the learning mode and emotional quotient is interesting to be studied as the basis 
of History Education development in order to create the Indonesian generation with a high understanding of historical values.

\section{Emotional Quotient}

The Emotional Quotient was used for the first time by Peter Salovey and John Mayer, and studied deeper by Daniel Goleman (1983). Salovey concept is recognized as the extent explaination of Multiple Intelligence concept developed by Howard Gardner. Howard work is the respond of Intelligence Quotient concept that has been developed since a long time ago.

According to Howard Gardner in Agus Efendi (2005), "in a human there are seven intelligence spectrum, which are 1) verbal intelligence, 2) visual intelligence, 3) logic-mathematicintelligence, 4) musical intelligence, 5) kinestetikintelligence, 6) intrapersonal intelligence, and 7) interpersonal intelligence, ... and the other supplement intelligence, 1) naturalist intelligence, 2) existential intelligence, and 3) spritual intelligence". Therefore, human intelligence spectrum based on Gardner Multiple Intelligence includes the ten human intelligences.

Emotional quotient is the merge of intrapersonal intelligence and interpersonal intelligence. Intrapersonal intelligence is an ability to understand others, "that is express in pleasure to make friends and the pleasure in joining various social activities and the unwillingness to be alone" (Julia Jasmine, 2007). Interpersonal intelligence is the corelative ability, which directed to the self that "expressed in the full awareness of inner feeling" (Julia Jasmine, 2007).

According to Deborah Mackin, "emotional quotient is a product of the amount of communication between the rational and emotional centers of the brain" (http://www.eiconsortium.org). Therefore, emotional quotient can also be understood in a dimension of human nature development as a person with a particular ability and interest and also the social creature that cannot live alone, and have to connect to another.

Emotional quotient is "the ability to self motivate and survive in facing a frustration, controlling the desire and not exceeding a happyness, controlling mood and controlling stress in order not to paralyzed the ability to think, empathy, and pray" (Daniel Goleman, 2006). Cooper and Sawaf in Zaim Elmubarok (2008) explain that emotional quotient is "the ability to feel, understand, and selectively applied the emotional power and sensitivity as the energy source and human influence.

\section{The Factors Affect Emotional Quotient}

Emotional quotient is a human emotion potential that is influenced by two factors, genetic and environment. In detail, Atkinson in Sri Sumaryati (2008) 
explain that emotional quotient is influenced by the following factor, 1) genetical factor that are the individual habits, 2) maturation, 3) excitement, and 4) external stimulation that result in an emotional reaction and the result of learning.

Emotional education is important, with the target of "improving the emotional and social ability level in children as a part of their regular education, not merely an education to save the "naughty" children, but as a series of the needed skill and understanding for the children" (Daniel Goleman, 2006).

In a different frame, Casmini (2007) explain that emotional quotient is influenced by two factors, the internal factor, the factor influenced by the brain emotional condition of a person; and eksternal factor, the factor that influence a person to change.

\section{Emotional Intelligence Elements}

Essencially emotional quotient has four competences, which are 1) undrstanding yourself or self-awareness, 2) managing yourself or selfmanagement, 3) understading others or social awareness, 4) managing othes or social skills (http://www.4nsights.com) According to Salovey in Daniel Goleman (2006), "emotional intelligence is the ability of five area, 1) recognizing personal emotion, 2) managing emotion, 3) self motivating, 4) recognizing other's emotion, and 5) maintaining relationship".

These five areas of emotional intelligence are adapted by Daniel Goleman in Suryaputra N. Awangga (2008) into fime basic element of emotional quotient:

1) Self awareness. Understanding what one felt in a time and using it to guide the self decision making, having a realistic measurement of a self ability and a strong self confidence.

2) Self controlling. Handling emotion in a particular way and make it have a postive effect in doing the assignment, sensitive to the impulse and able to delay enjoyful things before reaching a particular goal, able to do self curing after having so much pressure.

3) Motivation. Using the deepest desire as a guidance to reach a goal, help to do initiative and act effectively, and survive in facing failure and frustation.

4) Empathy. Sensing what other's feel, able to nderstand their perspective, develop a trusted relationship, and harmonize with various people.

5) Social skill. Good emotion handling when connecting with other people by accurately reading the situation and social network, interact well, and using this skill to influences and lead, negotiate and solving conflict, working together, and in a team work.

Cooper and Sawaf in Casmini (2007) said that "emotional quotient includes four aspects, 1) emotional literacy, 2) emotional fitness, 3) emotional depth, dan 4) emotional alchemy". 
Based in the above explaination, it can be understood that emotional quotient includes two important aspect, the awareness of self emotion and its controlling and development, and the will to connect with others based on the social awareness and skill.

\section{The Importance of Emotional Quotient}

Emotion is the integral part of human life because "emotion is a feeling with its particular thought, biological and psychological situation, and various tendency to act" (Agus Efendi, 2005). Human has a heart potencial or qalbu, that according to Toto Tasmara (2001), has three dimention, which are:

1) Fu'ad. The qalbu potential that associated to the sense, information processing, often symbolize as existing in the human brain;

2) Shard. Qalbu potential to feel and experience or having the emosional function;

3) Hawaa. The qalbu potential that move the desire. Therefore, it's clear that emotion takes part in developing a person personality.

Based on Daniel Goleman study, the emotional quotient contributes the $80 \%$ of someone successful life, and IQ only contribute about $20 \%$. In the context of learning, emotion affects the process and then out come. Therefore, by "considering the students emotion can help to accelerate their learning process" (Bobbi dePorter, dkk., 2000).

Based on the above explaination it can be concluded that emotional quotient contribute in accelerate the learning process, developing personality, and supporting a person success.

It will be explain further about the value clarification mode aplication in imrpoving hitorical value understanting among students based on the students' emotion.

\section{Research Methodolgy}

\section{Reseach Design and Variable}

This is an experimental research, because the result of this reseach will clarify the position of casual relationship among variables to be studied, the goal exists in the founding of the cause facts and the consequence facts of the various effectiveness of VCT (Value Clarification Technique) and conventional learning mode apllication in history lesson based on the students' emotional quotient. After that, comparison analysis was done for every independent variable at once, based on the factors interact to the dependent variable. The reseach design is using the 2 $\mathrm{x} 2$ factorial design with varian anlysis technique (Anava). The reseach result will explain how the variable connection will be observed, the independent variable 
in this research are (a) the learning process mode (VCT or Value Clarification Technique and Konvensional mode), and (b) the students emotional quotient. The dependent variable in this reseach is the historical value understanding. Based on the reseach variable, the reseach design can be seen in the table below:

Table 12.1. Reseach Analysis Design

\begin{tabular}{|c|c|c|}
\hline \multirow{2}{*}{ Emotional Quotient (B) } & \multicolumn{2}{|c|}{ Learning Mode (A) } \\
\cline { 2 - 3 } & VCT mode & Conventional mode \\
\hline High Emotional Quotient (B1) & $\mathrm{A} 1 \mathrm{~B} 1$ & $\mathrm{~A} 2 \mathrm{~B} 1$ \\
\hline Loe Emotional Quotient (B2) & $\mathrm{A} 1 \mathrm{~B} 2$ & $\mathrm{~A} 2 \mathrm{~B} 2$ \\
\hline
\end{tabular}

Information:

A1.B1 = The group with a high emotional quotient treated wit VCT learning process.

A1.B2 = The group with a low emotional quotient treated with conventional learning process.

A2.B1 = The group with a high emotional quotient treated with VCT learning process.

A2.B2 = The group with a low emotional quotient treated with conventional learning process.

Research Sample

In this reseach, the reseach sample is the grade XI student of XI SMA Negeri I Karangpandan class 2010/2011, one class for experimental class with 40 students and one class for control class with 35 students.

\section{Reseach Result and Discussion}

Hypothesis test is done by two line variant analysis technique (ANAVA) with the factorial design of $2 \times 2$, continued with Schefe Test, to find out which group is better significantly. The purpose of Two Line Variant Analysis is to investigate the two main effect and one interaction effect. The main effect is the different effect of learning process mode and the students' emotional quotient toward the historical value understanding. The interaction effect is the effect of learning process mode and the students' emotional quotient toward the historical value understanding. Normality and homohenity test was done before hypothesis test. The quantity statistic summary of the test result of historical value understanding can be seen in the bellow table: 
Table 12.2: The statistic quantity needed

\begin{tabular}{|c|c|c|c|c|}
\hline \multicolumn{2}{|c|}{$\begin{array}{c}\text { Learning Mode } \\
\text { Emotional Quotient } \\
\end{array}$} & $\begin{array}{l}\text { VCT } \\
\text { (A1) }\end{array}$ & $\begin{array}{c}\text { Conventional } \\
\text { (A2) }\end{array}$ & Total Amount \\
\hline \multirow{4}{*}{$\begin{array}{c}\text { High Emotional } \\
\text { Quotient } \\
\text { (B1) }\end{array}$} & $\mathrm{N}$ & 21 & 17 & 38 \\
\hline & $\sum \mathrm{x}$ & 1646,95 & 1200,86 & 2847,81 \\
\hline & $\sum \mathrm{x}^{2}$ & 129237 & 84943.69 & 208660 \\
\hline & $\mathrm{X}$ & 78,43 & 70,64 & 74,94 \\
\hline \multirow{4}{*}{$\begin{array}{c}\text { Low Emotional } \\
\text { Quotient } \\
\text { (B2) }\end{array}$} & $\mathrm{N}$ & 19 & 18 & 37 \\
\hline & $\sum \mathrm{x}$ & 1201,67 & 990,39 & 2378,57 \\
\hline & $\sum \mathrm{x}^{2}$ & 77017.69 & 77507.06 & 156379 \\
\hline & $\mathrm{X}$ & 63,25 & 65,38 & 64,29 \\
\hline \multirow[t]{4}{*}{ Total Amount } & $\mathrm{N}$ & 40 & 35 & 75 \\
\hline & $\sum \mathrm{x}$ & 2848,62 & 2377,76 & 5226,58 \\
\hline & $\sum \mathrm{x}^{2}$ & 206254.6 & 162450.8 & 368705,4 \\
\hline & $\mathrm{X}$ & 71,22 & 67,94 & 69,58 \\
\hline
\end{tabular}

Based on the calculation by SPSS 16,0 Program the ANAVA summary result as the whole can be seen in table 2

Table 12.3:

ANAVA 2x2 Calculation Result

Tests of Between-Subjects Effects

Dependent Variable: Historical Value Understanding

\begin{tabular}{|l|r|r|r|r|r|}
\hline Source & $\begin{array}{l}\text { Type II Sum } \\
\text { of Squares }\end{array}$ & df & Mean Square & \multicolumn{1}{|c|}{ F } & \multicolumn{1}{c|}{ Sig. } \\
\hline Corrected Model & $2740.926^{\mathrm{a}}$ & 3 & 913.642 & 36.778 & .000 \\
Intercept & 364200.639 & 1 & 364200.639 & 14660.657 & .000 \\
$\mathrm{~A}$ & 153.011 & 1 & 153.011 & 6.159 & .015 \\
$\mathrm{~B}$ & 2081.216 & 1 & 2081.216 & 83.778 & .000 \\
$\mathrm{~A} * \mathrm{~B}$ & 458.948 & 1 & 458.948 & 18.475 & .000 \\
Error & 1763.785 & 71 & 24.842 & & \\
Total & 368705.350 & 75 & & & \\
Corrected Total & 4504.711 & 74 & & & \\
\hline
\end{tabular}

a. R Squared $=.608$ (Adjusted R Squared $=.592)$

Based on the two lines ANAVA calculation above, can be concluded that

First hypotheses:

The difference influence of VCT model application to the conventional mode towards the historical values understanding of the student of Grade XI, first semester of Sekolah Menengah Atas Negeri Karangpandan, class of 2010/2011 
Based on ANAVA table, the result of $\mathrm{F}_{\text {hitung }}=6,159>\mathrm{F}_{\text {tabel }}=3,11$ means that the first statistic hypotheses (Ho) pertama is rejected. And $\mathrm{H} 1$ is accepted. Therefore, it can be conluded that there is an average difference of the historical value understanding bertween the VCT mode and conventional mode, the test result of VCT mode students is better than the conventional mode.

The result of this reseach shows that learning process mode, VCT (Value Clarification Technique) and convensional, has a significant influence in the SMA Negeri Karangpandan student understanding of historical values.

The score improvement of historical value understanding is better in VCT learning mode because the development of historical value to the student was done by harmonizing the students' current values with the new values to be conveyed, that Darmayati Zuchdi (2008) called "values inquiry process". There is a value clarification process to be harmonized in the middle of various and dilemmatic new values. This harmonization will protect the value stability as the basic of students' character in the value understanding alteration that is more complex because it is found by the student's themselve through a rational process.

The harmonization of historical values is stronger because "VCT learning process is conduct in the freedom to choose, respect, and act" (Wina Sanjaya, 2008). By the freedom to choose students will feel more comfortable and not forced because the students' had their own choice. Moreover, it extended with respect and act process which results in a more harmonious development of affection and psychomotor.

On the contrary, in the conventional learning process, the learning process is focused more in helping the student to have the ability to live together harminously, caring, and, felt what the other felt. The teacher dominates the process. Moreover, in the conventional learning process, the cognitive aspect did not get enough attention because the learning process is based on the assumption that the value development is not the same with rational cognitive development. As the result, the value understanding development does not involved the intelectual development.

Based on the discussion above, based on the empirical data and theoretical perspective, it is quite logic to say that VCT has a better influence in the historical value understanding than the conventional mode.

\section{Second Hypothese:}

The difference influence of the high emotional quotient to the low emotional quotient towards the historical values understanding of the student of Grade XI, first semester of Sekolah Menengah Atas Negeri Karangpandan, class of 2010/2011

Based on ANAVA table, the result of $\mathrm{F}_{\text {hitung }}=83,778>\mathrm{F}_{\text {tabel }}=3,11$ means that the first statistic hypotheses (Ho) pertama is rejected. And $\mathrm{H} 1$ is accepted. Therefore, it can be concluded that there is an average difference of historical history understanding between students with high emotional quotient and the 
low emotional quotient. The student with high emotional quotient is better than the student with low emotional quotient.

The result of this research shows that the emotional quotient (high and low) significantly affect the students' historical value understanding of SMA Negeri Karangpandan students. It can be seen in the average score of history lesson.

Student with high emotional quotient can understand and manage their emotion that really helps their value developing process through the development of emotional connection to the expected historical values. Bobbi DePotter (2005) explains that "there is a storng connection between emotional involvement, short memory, and learning process". This learning process is the basis of the development of student's value understanding. In addition, high emotional quotient results in a strong motivated student to develop a mature person with a good communication quality with others that strengthen their value understanding.

On the contrary, student with low emotional quotient doesn't have enough ability to manage their emotion, which results in the longer process of understanding the historical values. Furthermore, a low emotional quotient student cannot motivate themseve and develop a good communication with others. Value understanding development need a strong motivation and interacts with others.

Based on the discussion above, based on the empirical data and theoretical perpective, it is quite logic to say that high emotional quotient better influences in the historical value understanding than the low emotional quotient student.

\section{Third Hypothesis:}

The interaction of learning process mode and emotional quotient to the historical values understanding of the student of Grade XI, first semester of Sekolah Menengah Atas Negeri Karangpandan, class of 2010/2011

To understand whether there is influences interaction of learning process mode application to the emotional quotient and the historical values understanding. $\mathrm{F}_{\text {Hitung }} 18,465$ was gained. $\mathrm{F}_{\text {Tabel }}$ is 3,11. Because $\mathrm{F}_{\text {Hitung }}$ is bigger than $\mathrm{F}_{\text {Tabel, }}$, zero hypothesis is rejected. This means that there is interaction between learning process mode and the students' emotional quotient toward the historical value understanding. Next step is a further test using Scheffe test. The interaction form can be seen in the picture 1 below: 


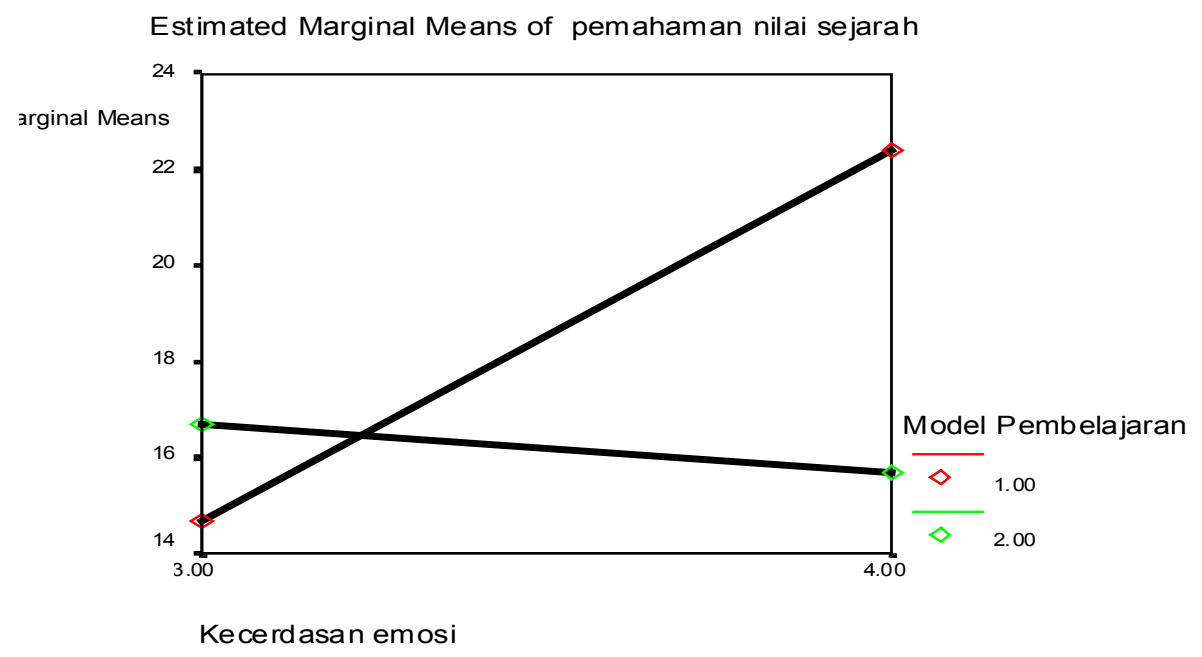

Picture 12.4. Interaction of learning process model and emotional quotient towards historical values understanding.

Based on the picture above, it can be seen that the average score of historical value understanding, for each mode, the learning process, and student's emotional quotient is comparison pair bertween two means. This is the configuration component. In the interaction between the learning process mode and the high emotional quotient, there is two configuration component suitable for the research purpose: The first component is the score means of historical value understanding test result of those who have high emotional equotient and treated with VCT mode and the second Conventional component is the score means of historical value understanding test result of those who have low emotional quotient and treated by VCT mode. Both configurations are tested as explain in the second and third hypothesis test.

Based on the analysis, the next step is advanced test The result, by using Scheefe tes, is as follows:

a. There is a difference in the average value of 7.7874 in VCT Mode for students with high emotional quotient (78.42) with the conventional mode for high emotional intelligence (70.64). With a standard error of 1.626 and a significance level of $0.000(0.000<0.05)$ which means that between the average value of the VCT model on students with high emotional intelligence with the conventional model on students with high emotional quotient is different.

b. There is a difference in the average value of 15.1804 of the VCT mode for students with high emotional quotient (78.42) with VCT mode for low emotional quotient (62.25). With a standard error of 1.578 and a significance level of $0.000(0.000<0.05)$ means that between the average value of the VCT mode on students with high emotional quotient with VCT mode on students with low emotional intelligence is different.

c. There is a difference in the average value of 13.0429 of the VCT mode for students with high emotional quotient (78.42) with an average value of 
historical values understanding with the conventional model for students with low emotional quotient (65.38). With a standard error of 1.600 and a significance level of $0.000(0.000<0.05)$ which means that between the average value of the VCT model on students with high emotional intelligence with the conventional mode on students with low emotional intelligence is different

d. There is a difference in the average value of 7.3930 on the average of historical values understanding in conventional mode for students with high emotional quotient (70.64) with low emotional quotient in VCT mode (63.25). With a standard error of 1.663 and 0.001 significance level $(0.001<0.05)$ which means that between the average value of the conventional model on students is different

e. There is a difference in the average value of 5.2555 on the historical value understanding with the conventional mode for students with high emotional quotient (70.64) with an average value historical value understanding with the conventional mode for students with low emotional quotient (65.38). With a standard error of 1.685 and 0.027 significance level $(0.027<0.05)$ which means that the historical value understanding with the conventional mode for students with high emotional quotient with an average value of historical value understanding with the conventional mode for students with emotional quotient is different

f. There is a difference in the average value of 5.7 on the average value of historical value understanding with VCT mode for students with low emotional quotient (63.25) with an average value of historical value understandingwith the conventional mode for students with low emotional quotient (65.38). With a standard error of 1.639 and 0.639 significance level (0.639>0.05) which means that between the average value of historical value understanding in VCT mode for low emotional quotient students with an average value of historical value understanding withconventional model for low emotional quotient students is not different

The result of this reseach shows that the interaction of the learning process mode and emotional quotient affect the students' historical value understanding of SMA Negeri Karangpandan students at the same time. This is because historical value understanding is a result of learning process influenced by various factors, internally or externally. "The internal factor (getenical) are talent, intelligence (intellectual, emitonal, and spiritual), and temperament, the external factor are education process, self experience, and the interaction with the environment" (Sjarkawi, 2008; Din Zainuddin, 2004).

Based on the Scheffe test we can see that the student with the higest hitorical understanding score is the student who learned through VCT with high emotional quotient. This is very possible because a high quality learning mode and the high emotional quotient is an ideal condition that is very helpful for students' value understanding development. 
On the contrary, the students who have the lowest historical value understanding are the students who were taught by conventional learning process and have lower emotional quotient. This is possible because students did not get enough learning process to understand the value rationally, whereas the ability to manage emotion is also lower, it's a logic reason why the value understanding is not optimal.

Based on the empirical and tehrotical persperctive of the discussion above, it is very logic that the learning process mode and emotional quotient affect the students' historical value.

\section{Conclusion}

Data analysis result shows that there is difference historical value understanding between the student treated with VCT and conventional. Student of VCT mode has a better historical value understanding than the conventional mode. This means that there is interaction between learning process mode and the students' emotional quotient toward the historical value understanding. From the analysis it can be concluded that:

1. Based on the data analysis, there is a difference of historicalvalue understanding bertween the student who learn with VCT and conventional learning process mode. VCT mode result in a better historical value understanding than the conventional mode.

2. There is a difference historical value understanding between the higher Emotional quotient students. Higher quotient students have a better historical value understanding than the lower one.

3. There is influences interaction between learning process mode and the students' emotional quotient toward the historical value understanding.

Based on the result of this reseach, there are several things to be recommended:

1. Learning process approach of VCT mode can be a learning process alternative mode in History lesson that had been considered as an unimportant lesson tested in Ujian Nasional (National Examination), and the learning process has been considered uninteresting and unchalanged because student has no chance to explore their individual potential to improve their historical value understanding. By VCT mode the teacher-student relationship would be very close and more comfortable, thus a fun learning situation would be created, and expected to improve the study competence.

2. Higher emotional quotient has better influence than the lower one in the historical value understanding. The student's emotional quotient should be improved integratively in the history learning process, for example through PTK (penelitian tindakan kelas/ class act reseacrh) to improve the students' emotional quotient.

3. Many research variable have not been explained deeply in this research, such as the competence achievement measurement that is only meausre the 
students' cognitive aspect, because the history lesson competence evaluation is not only the cognitif. Therefore, it is recommended to do a further research to improve the affective aspect, to complete the students competence evaluation of hostory lesson.

\section{REFERENCES}

Anderson, L. W., dkk. (2001). A Taxonomy for Learning Teaching and Assesseing: A Revesion of Bloom's Taxonomy of Educational Obectives. New York: Longman.

Agustian, A.G. (2007). Rahasia Sukses Membangun Kecerdasan Emosi dan Spiritual : ESQ Emotional Spiritual Quotient. Jakarta: Arga

Arismantoro. (2008). Tinjauan Berbagai Aspek Character Building: Bagaimana Mendidik Anak Berkarakter?. Yogyakarta: Lemlit UNY-Tiara Wacana

Casmini. (2007). Emotional Parenting: Dasar-Dasar Pengasuhan Kecerdasan Emosi Anak. Yogyakarta: Pilar Media

Darmadi, H. (2007). Dasar Konsep Pendidikan Moral: Landasan Konsep Dasar dan Implementasi. Bandung: Alfabeta

Darmiyati, Z. (2008). Humanisasi Pendidikan. Jakarta: Bumi Aksara

David, L.ACriticalAnalysis of Value Clarification.(http://www.ApologeticsPress. org yang diakses tanggal 7 September 2009).

Daniel, M \& David Reynolds. (2008). Effective Teaching: Teori dan Aplikasi. (Edisi Terjemahan oleh Helly Prajitno Soetjipto dan Sri Mulyatini Soetjipto). Yogyakarta: Pustaka Pelajar

Deborah, M. Emotional Intelligence. (http://www.eiconsortium.org yang diakses tanggal 7 September 2009).

dePorter, B., Mark Reardo, \& Sarah Singer-Nourie. (2000). Quantum Teaching: Mempraktikkan Quantum Learing di Ruang-Ruang Kelas. (Terjemahan Ary Nilandari). Bandung: Kaifa

Dick, W, Lau Carey, \& James O. Carey. 2001. The Systematic Design of Instructions. New York: Longman.

Efendi, A. (2005). Revolusi Kecerdasan Abad 21: Kritik MI, EI, AQ \& Successful Intelligence atas $I Q$.

Ginnis, P. (2008). Trik\& Strategi Mengajar: Strategi Meningkatkan Pencapaian Pengajaran di Kelas. Jakarta: PT Indeks

Goleman, D. (2006). Emotional Intelligence (Edisi Terjemahan oleh T. Hermaya). Jakarta: Gramedia Pustaka Utama

Hoerr, T. R. (2007). Buku Kerja Multiple Intelligences Pengalaman New School di ST. Louis, Missouri, AS, dalam Menghargai Aneka Kecerdasan Anak (Edisi Terjemahan oleh Ary Nilandari). Bandung: Kaifa.

Jasmine, J. (2007). Mengajar dengan Metode Kecerdasan Majemuk: Implementasi Multiple Intelligences. (Edisi Terjemahan oleh Purwanto). Bandung: Nuansa 
Lee H. Ehman. 1980. The American School in The Political Socialization Process. Indiana: Indiana Universuty

Mappadjantji, A, A. (2005). Kemandirian Lokal Konsepsi Pembangunan, Organisasi, dan Pendidikan dari Pespektif Sains Baru. Jakarta: Gramedia Pustaka Utama

Morison, G. R., Steven M. R, Jerold E. K. (2001). Designing Effective Instruction. New York: John Wiley \& Sons, Inc.

Moerdiono. (1991). Menuju Nasionalisme Gelombang Ketiga. Jakarta: Prisma Pustaka LP3ES Indonesia

Nasikun dkk. (1996). Nasionalisme Refleksi Kritis Kaum Ilmuwan. Yogyakarta: Pustaka Pelajar

Notosusanto, N. (1979). Sejarah Demi Masa Kini . Jakarta: UI Press

Senen, A. dan Imam, B. (2000). Tantangan Guru Sejarah: Pesan Sejarah sebagai Konsep Pendidikan Nilai" dalam Jurnal Penelitian Evaluasi, Nomor 3 Tahun II 2000.

Sights. Managing with Emotional Intelligence: Develoing Empathy. (http:// www.4nsights.com diakses tanggal 7 September 2009).

Roblyer, M.D., Jack Edward, dan Mary Anne Havriluk. 1997. Integrating Educational Technology into Teaching. New Jersey: Prentice-Hall.Inc.

Kartodirdjo, S. (1982). Pengantar Sejarah Indonesia Baru: Sejarah Pergerakan Nasional dari Kolonialisme Sampai Nasionalisme. Jakarta: Gramedia

Simon, S. B. \& Leland W. H. The Values Clarification Approach. (http://www. ApologeticsPress.org yang diakses tanggal 7 September 2009)

Sjarkawi. 2008. Pembentukan Kepribadian Anak: Peran Moral, Intelektal, Emosional, dan Sosial sebagai Wujud Integritas Membangun Jati Diri. Jakarta: Bumi Aksara

Sudarsono, J. (1991). Orang Awam, Keadilan Ekonomi Politik dan Nasionalisme. Jakarta: Prisma Pustaka LP3ES Indonesia

Suryaputra N. A. (2008). Tes EQ Plus: Menakar Peluang Sukses Anda dengan Uji Latih Kecerdasan Emosi. Yogyaarta: Pustaka Pelajar.

Soekamto, T dan Saripuddin, U.W. (1996). Teori Belajar dan Model-Model Pembelajaran. Jakarta: Pusat Antar Universitas-Depdikbud.

Sanjaya, W. (2008). Strategi Pembelajaran Berorientasi Standar Proses Pendidikan. Jakarta: Kencana Prenada Media Group.

Tasmara, T. (2001). Kecerdasan Ruhaniah (Transcendental Intelligence). Jakarta: Gema Insani.

Zaim Elmubarok. 2008. Membumikan Pendidikan Nilai: Mengumpulkan yang Terserak, Menyambung yang Terputus, dan Menyatukan yang Tercerai. Bandung: Alfabeta.

Zainuddin, D. (2004). Pendidikan Budi Pekerti dalam Perspektif Islam. Jakarta: Al-Mawardi Prima.

Zuriah, N. (2007). Pendidikan Moral dan Budi Pekerti dalam Perspektif Perubahan. Jakarta: Bumi Aksara 